\title{
Spirituality and Quality of Life and Its Effect on Depression in Older Adults in Mexico
}

\author{
Ana Luisa González-Celis ${ }^{1}$, Juana Gómez-Benito ${ }^{2}$ \\ ${ }^{1}$ Division of Research and Graduate, Faculty of Higher Education Iztacala, National University Autonomous of \\ Mexico, Mexico City, Mexico \\ ${ }^{2}$ Department of Methodology of Behavioral Sciences, Faculty of Psychology, University of Barcelona, \\ Barcelona, Spain \\ Email: algcr10@hotmail.com, juanagomez@ub.edu
}

Received December $20^{\text {th }}, 2012$; revised January $27^{\text {th }}, 2013$; accepted February $24^{\text {th }}, 2013$

\begin{abstract}
The quality of life (QOL) appears as an object of study of psychology, as a central component of human well-being. The quality of life in the elderly is especially relevant because as the years go the older persons can have lost health, the social role, the cognitive functioning, the power financial and their family. The purpose of the study is to evaluate the impact of psychological variables associated with quality of life in Mexican elderly. A sample of 75 elderly people between 60 and 87 years (mean $=65, \mathrm{SD}=9.41$ ), 45 women and 30 men, assigned to a health clinic. QOL was measured with the WHOQOL, and an ex post facto design, three groups were formed by the level obtained with depressive symptoms GDS: (G1) absent $\left(\mathrm{n}_{1}=42\right)$, (G2) mild $\left(\mathrm{n}_{2}=19\right)$ and $(\mathrm{G} 3)$ moderate-severe $\left(\mathrm{n}_{3}=14\right)$. An acceptable correlation between QOL and spirituality $(\mathrm{r}=.523, p<.0001)$. A negative association between QOL and depression $(\mathrm{r}$ $=-.482, p<.0001)$. The QOL showed differences between groups with different levels of depressive symptoms $\left(\mathrm{F}_{(2.72)}=15.212, p<.0001\right)$. The QOL exhibited differences between diseased subjects $(\mathrm{QOL}=$ $61.19)$ and non-diseased $(\mathrm{QOL}=66.61)(\mathrm{t}=2.025, p<.046)$. There were differences in the level of spirituality $(\mathrm{Sp})$ among elderly patients $(\mathrm{Sp}=64.77)$ and non-elderly patients $(\mathrm{Sp}=75.0)(\mathrm{t}=2.37, \mathrm{df}=97, p$ $<.02)$. The QOL in the elderly can be improved with psychological interventions to help reduce depression, where spirituality can be a resource and coping strategy to strengthen other areas of aging.
\end{abstract}

Keywords: Spirituality; Quality-of-Life; Depression; Older Adults Mexicans

\section{Introduction}

Mexico is in a period of change in the trend of the population, which is projected in the next years much of the population will be elderly.

Several sources (CONAPO, 2001, 2006; Partida, 2006; United Nations, 2007; World Bank, 2009) have given explanation to this phenomenon, attributing it mainly to advances in the medical field, thanks to this the mortality rate has decreased and life expectancy has increased from 34 years old in 1930 to over 75 years old in 2005 (INEGI, 2009), allowing one hand a death to a later age and on the other a lower infant mortality.

Thus the combination of life expectancy increasing and a fall in the fertility rate, causes a significant increase in the average age, a rising proportion of older adults, and therefore a need for greater attention to these individuals.

But if the life expectancy has increased it does not necessarily indicate that conditions have improved, also that living more years, means more health risks and does not necessarily represent a complete satisfaction (González-Celis, 2010).

Thus the quality of life (QOL) appears as an object of study of psychology, as a central component of human well-being that is closely related to other aspects of functioning, such as health (Johansson, Grant, Plomin, Pederson, Ahem, Berg et al., 2001; Litwin \& Shiovitz-Ezra, 2006), the coping, the problem solving, the self-efficacy (Bandura, 1977, 1999; González-Celis, 2009a, 2012b), the development of social skills (Acuna-Gurrola \& González-Celis, 2011) and the depressive symptoms (Gon-
zález-Celis, 2009b).

Evaluate the quality of life in the elderly is especially relevant because according to the years go in the life of an individual, is undergoing a series of transformations that result in gains and losses, including health, the social role, cognitive functioning, the family and the economic status, loneliness, and anxiety, among others (Nieto, Abbot, \& Torres, 1998; Pinquart \& Sörensen, 2001; Rivera-Ledesma, Montero, González-Celis, \& Sanchez-Sosa, 2007; Rowe \& Kahn, 1997; Sanchez-Sosa \& González-Celis, 2002, 2006).

One of the dimensions of quality of life is social support, and in the elderly appears as a measure of the well-being (Burnett, Regev, Pickens, Prati, Aung, Moore, \& Bitondo, 2006; Jackson, 2006).

One of the most common problems found in the elderly, is the presence of depressive symptoms.

One strategy to coping with the loss in the elderly is spirituality (González-Celis, 2012a; González-Celis \& Araujo, 2010; González-Celis \& Lázaro, 2007; González-Celis \& Padilla, 2006).

It is from this kind of approach that studies on quality of life (QOL) come to know and give better service to the needs of the elderly.

So the purpose of the study is to evaluate the impact of psychological variables associated with the QOL in older adults Mexicans.

\section{Objectives}

The principal objective is to examine if the social support 
and spirituality are measures of the quality of life in the elderly and its effect on depression.

Other objective is to test the association between the social support, depression and spirituality.

As well as to evaluate the differences in QOL, social support, depression, and other additional measures, gender and condition of health.

And to test the differences in the domains of QOL in older people with different groups depressive symptoms.

\section{Method}

\section{Participants}

A sample of 75 elderly, aged between 60 and 87 years old (mean $=65, \mathrm{SD}=9.41)$, 45 were women and 30 men, assigned to a health clinic in a lower-class urban area of Mexico State. The average educational level was of basic education. Regarding marital status, $63 \%$ were married or with partners, $34 \%$ widowed and $3 \%$ singles.

They completed three instruments plus a sheet socio demographic data also they gave voluntarily, their informed consent.

Under an ex post facto design, formed three groups of subjects by the level of depressive symptoms according to the score obtained by the Geriatric Depression Scale: (G1) absent $\left(\mathrm{n}_{1}=42\right),(\mathrm{G} 2)$ mild $\left(\mathrm{n}_{2}=19\right)$ and $(\mathrm{G} 3)$ moderate-severe $\left(\mathrm{n}_{3}=\right.$ 14).

\section{Measures}

It was applied a battery composed of three measuring instruments psychological and sheet socio demographic data.

Sociodemographic questionnaire. As an interview through 20 both open and closed questions, general data were obtained from subjects who participated in the study (name, age, gender, marital status and condition about health).

Quality of Life (WHOQOL-100), prepared by the World Health Organization (WHO-Group, 1996, 1997, 1998a, 1998b), in its extended version (Power, Bullinger, \& Harper, 1999), translated and adapted to Spanish-Mexican by González-Celis (2002). It features 100 items, with which measures the quality of life in general. It includes six domains of quality of life: physical health, independence, psychological health, social relationships, environment and spirituality. Contains 24 specific facets with four questions each ( 96 items) and a general facet of four items designed for to measure "Quality of Life Global" and "Overall Health". It was got a total score from 0 to 100 , with higher scores indicating better quality of life. Also the score of the QOL has six specific scores one for each domain. To answer the questionnaire asked the participants that their responses they referred to two weeks earlier.

Subjective Well-being Scale PCG (Philadelphia Geriatric Center) for the elderly, written and reviewed by Lawton in 1975 which measures the overall subjective well-being older adults (Andrews \& Robinson, 1991) (Spanish version by González-Celis, 2002). The scale is composed of three factors: agitation, attitude to their own aging and loneliness. The scale values range from 0 (lowest level of well-being) to 22 (highest), which refers to the values of satisfaction, peace or achievement. The answer choices are dichotomous and nominal -yes/no-, and two open questions in the factor 3, items 1 and 5.

Geriatric Depression Scale, GDS, (Yesavage, Brink, Rose, Lum, Huang, Adey, \& Leiver, 1983). The short version with 15 items of the Geriatric Depression Scale (GDS), adapted to Mexican older population by González-Celis \& Sánchez-Sosa (2003). The total qualification is obtained by adding scores of 0 (zero), which equals to lack of depression, to a maximum of 15 points. Scores of five points or more indicate a presence of depressive symptoms.

\section{Procedure}

It requested authorization to a health clinic located in the state of Mexico, for the implementation of quality of life assessments to seniors.

It contacted people to invite them to participate in the study, reporting the assessment of the QOL, in order to know how it was in their physical, psychological and emotional. Those interested in participating were given by the interviewers and were programmed according to appointment availability.

Later, in a cubicle of the health clinic, there was a single session lasting approximately one hour, where it conducted the reading and signing the informed consent, followed by filling the data sheet and socio demographic implementation of the three questionnaires as an interview, in the same order for all.

\section{Results}

An acceptable correlation between QOL and social support ( $\mathrm{r}$ $=.599, p<.0001)$, and quality of life and spirituality $(\mathrm{r}=.523$, $p<.0001)$.

The results also revealed a moderate but significant negative association between QOL and depression $(\mathrm{r}=-.482, p$ $<.0001)$.

Also found moderate, significant and negative correlation between depression and social support $(\mathrm{r}=-.397, p<.0001)$, but not with depression and spirituality.

The QOL showed differences between groups with different levels of depressive symptoms $\left(\mathrm{F}_{(2,72)}=15.212, p<.0001\right)$ (Figure 1).

The quality of life exhibited difference between diseased subjects $(\mathrm{QOL}=61.19)$ and non-diseased $(\mathrm{QOL}=66.61)(\mathrm{t}=$ $2.025, p<.046)$.

The quality of life showed gender differences significant $(\mathrm{t}=$ $2.005, \mathrm{df}=74, p<.049)(\mathrm{QOL}$ of women $=60.80$, QOL of men $=65.42$ ).

Score of support social was statistic and significantly difference between groups with different levels of depressive symptoms $\left(\mathrm{F}_{(2,84)}=6.710, p<.002\right)$.

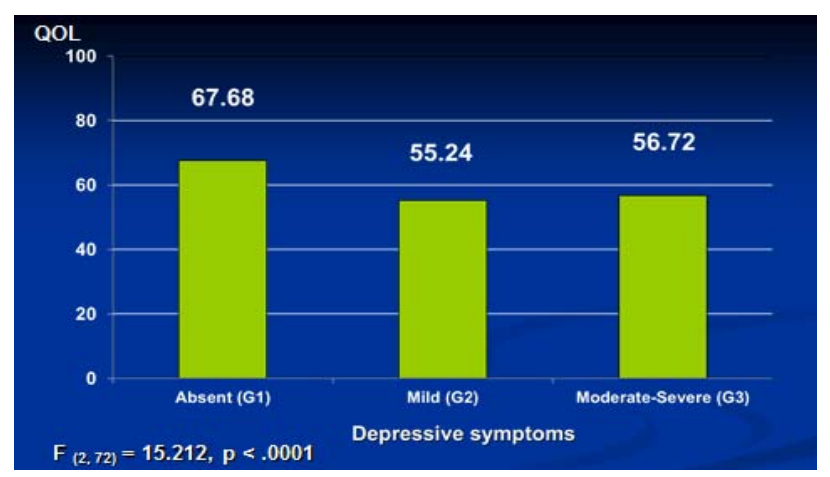

Figure 1.

Quality of life scores for each group with different levels of depressive symptoms. 
Table 1.

Comparison of quality of life scores for each domain between the various groups with depressive symptoms.

\begin{tabular}{ccccccc}
\hline \multirow{2}{*}{$\begin{array}{c}\text { Groups with depressive } \\
\text { symptoms }\end{array}$} & \multicolumn{5}{c}{ Quality of life domains } \\
\cline { 2 - 6 } & Physical health & Psychological health & Independence & Social relations & Environment & Spirituality \\
\hline Absent (G1) & 68.29 & 68.80 & 68.96 & 64.89 & 64.16 & 70.31 \\
Mild (G2) & 49.37 & 51.47 & 51.34 & 54.08 & 54.87 & 64.44 \\
Moderate-severe (G3) & 47.40 & 51.13 & 50.89 & 53.39 & 55.30 & 67.56 \\
Total & 59.64 & 60.06 & 60.32 & 59.79 & 60.29 & 68.08 \\
F & 19.843 & 29.018 & 19.543 & 6.710 & 9.221 & .764 \\
$p$ & $<.0001$ & $<.0001$ & $<.0001$ & $<.0002$ & $<.0001$ & $>.469$ \\
\hline
\end{tabular}

No differences in social support, spirituality and and the number of depressive symptoms between gender.

No differences in social support and depressive symptoms between elders who report being sick and healthy elderly.

There was difference in the level of spirituality (Sp), among elderly ill $(\mathrm{Sp}=64.77)$ and healthy elderly $(\mathrm{Sp}=75.0)(\mathrm{t}=2.37$, df $=97, p<.02)$.

Comparing levels of quality of life in each of the six domains of quality of life with the average obtained by standard WHOQOL-Group (1998a, 1998b) (Range $=62.25-71.75)$, was observed in the case of elderly sample Mexican, the quality of life scores were lower in all domains (Physical Health, Psychological Health, Independence, Social Relations and the Environment), except for the domain of Spirituality (68.07) (Figure 2)

Finally, when comparing the quality of life scores for each domain, between groups with different levels of depressive symptoms (Table 1). Note that there is enough statistical evidence to prove the difference in quality of life scores between groups with different levels of depressive symptoms, in the domains of Physical Health, Psychological Health, Independence, Social Relations, and Environment; found higher scores for quality of life in the elderly group without depressive symptoms, and lower scores for quality of life in groups of elders who had mild, moderate or severe depressive symptoms; not for the domain of spirituality, where the quality of life score was the same and slightly higher for all groups of elderly without depressive symptoms, or for those who showed symptoms of mild depression, moderate or severe.

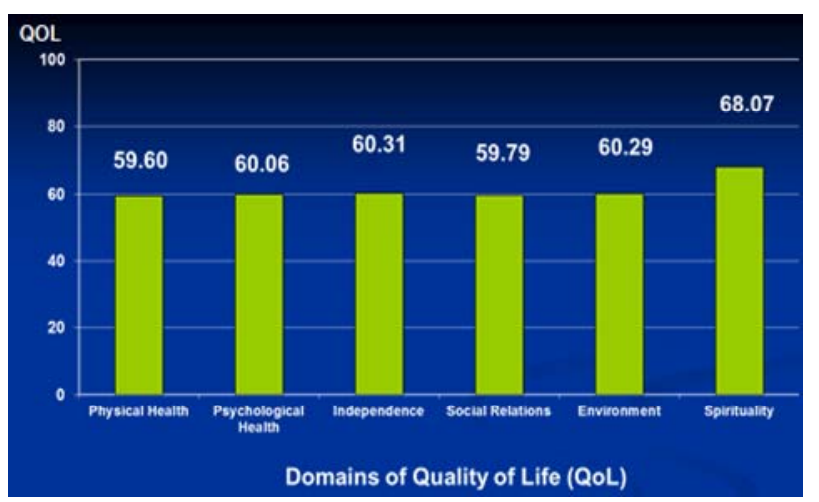

Figure 2.

Comparison of quality of life scores for each domain, in a sample of 75 elders of the State of Mexico and the standard (62.25 - 71.75) of WHO.

\section{Discussion}

In a report prepared by the WHO (Power, Bullinger, \& Harper, 1999), the global standard established by 15 countries to consider a good QOL, is a score ranging from 70 to 75 in each of the domains, which, the results of the study are not very flattering. In analyzing the results, spirituality highlighted as an important element in the functioning of the QOL, agreeing with Viamonte (1993) on the inclusion of this aspect as one of five to maintain a balance in the well-being of the individual, possibly as a strategy coping used by older adults. Spirituality not only as belonging to any group or association of a religious, but as a belief in something that affects daily life and sense of transcendence (Montero \& Sierra, 1996).

Although no significant association was found between scores on the domain of spirituality and attending a religious group, it was observed that the people who do attend a group scored higher in the domain of spirituality than those who do not, what may reflect that membership in a group helps to increase the level of spirituality, which would impact the quality of life of people.

Also it can be concluded that depression is a modulating variable of QOL in older adults. Elderly without depressive symptoms had higher levels of quality of life than those with mild, moderate or severe. However, the QOL was not differ for older people with different levels of depression, exclusively to the domain of spirituality, hence it is interesting to ask, if spirituality can be used as a protective factor when used as a resource for coping with the depressive symptoms.

Finally QOL in elderly probably be improved with psychological interventions (González-Celis, Chavez, \& Tron, 2011, Gonzalez-Celis \& Sanchez-Sosa, 2003) to help reduce the presence of depressive symptoms. Spirituality can be used as a resource and also as a coping strategy (González-Celis, 2012a; Rivera-Ledesma, 2003) to strengthen other areas of aging.

\section{Acknowledgements}

This paper is product of a research sponsored by National University Autonomous of Mexico, through a grant of the Program PASPA 2012, for to work half of sabbatical in the University of Barcelona, who obtained the first author under the guidance of the second.

\section{REFERENCES}

Acuña-Gurrola, M. R., \& González-Celis, R. A. L. (2011). Habilidades 
sociales y calidad de vida en adultos mayores mexicanos de un centro recreativo. In J. M. Román-Sánchez, M. A. Carbonero-Martín, \& J. D. Valdivieso-Pastor (Eds.), Educación, Aprendizaje y Desarrollo en una Sociedad Multicultural (pp. 1304-1316). Madrid: Ediciones de la Asociación Nacional de Psicología y Educación.

Andrews, F. M., \& Robinson, J. P. (1991). Measures of subjective well-being. In J. P. Robinson, P. R. Shaver, \& L. S. Wrightsman (Eds.), Measures of personality and social psychological attitudes (pp. 61-114). San Diego: Academic Press, Inc.

Bandura, A. (1977). Self-efficacy: Toward a unifying theory of behavioral change. Psychological Review, 84, 191-215. doi:10.1037//0033-295X.84.2.191

Bandura, A. (1999). Autoeficacia: cómo afrontamos los cambios de la sociedad actual. Bilbao: Desclée de Brouwer. doi:10.1017/CBO9780511527692

Burnett, J., Regev, T., Pickens, S., Prati, L., Aung, K., Moore, K., \& Bitondo, C. (2006). Social networks: A profile of the elderly who self-neglect. Journal of Elder Abuse \& Neglect, 18, 35-49. doi:10.1300/J084v18n04 05

CONAPO (2001). Índices de desarrollo 2000. URL (last checked 10 July 2011).

http://www.conapo.gob.mx/publicaciones/indicesoc/IDH2000/desarr ollo_humano.pdf

CONAPO (2006). Proyecciones de la población de México 2005-2050. URL (last checked 23 October 2012).

http://www.conapo.gob.mx/es/CONAPO/Proyecciones_de_la_pobla cion de Mexico 2005-2050

González-Celis, R. A. L. (2002). Efectos de intervención de un programa de promoción a la salud sobre la calidad de vida en ancianos. Ph.D. Thesis, México: Facultad de Psicología, UNAM.

González-Celis, R. A. L. (2009a). Autoeficacia para realizar actividades cotidianas (AeRAC) en ancianos mexicanos. In A. L. González-Celis, R. (Ed.), Evaluación en psicogerontología (pp. 47-74). México: Editorial Manual Moderno.

González-Celis, R. A. L. (2009b). Composición factorial del inventario de depresión de Beck en ancianos mexicanos. Journal of Behavior, Health \& Social Issues, 1, 15-28.

González-Celis, R. A. L. (2010). Calidad de vida en el adulto mayor. In L. M. Gutiérrez-Robledo, \& J. H. Gutiérrez-Ávila (Eds.), Envejecimiento Humano. Una Visión Transdisciplinaria (pp. 365-378). México: Instituto de Geriatría. Secretaría de Salud.

González-Celis, R. A. L. (2012a). Ch. 9: Estilos de afrontar el estrés ante el envejecimiento. In S. Galán-Cuevas \& E. J. F. CamachoGutiérrez (Eds.), Estrés y salud: Investigación básica y aplicada (pp. 115-130). México: Editorial Manual Moderno. Universidad Autónoma de San Luis Potosí.

González-Celis, R. A. L. (2012b). La autoeficacia en las actividades cotidianas. In L. M. Gutiérrez-Robledo \& D. KershenobichStalnikowitz (Eds.), Envejecimiento y salud. Una propuesta para un plan de acción (pp. 179-191). México: Academia Nacional de Medicina de México, Academia Mexicana de Cirugía, A. C. Instituto de Geriatría, Universidad Nacional Autónoma de México.

González-Celis, R. A. L., \& Araujo, V. A. V. (2010). Estrategias de afrontamiento ante la muerte y calidad de vida en adultos mayores. Revista Kairós-Gerontologia, São Paulo, 13, 167-190.

González-Celis, R. A. L., Chávez, B. M., \& Trón, A. R. (2011). Calidad de vida y adaptación psicológica en una muestra de ancianos que habitan en la ciudad de México. Revista Memorialidades. Universidade Estadual De Santa Cruz. DFCH-Núcleo De Estudos Do Envelhecimento, 16, 29-53.

González-Celis, R. A. L., \& Lázaro, L. G. (2007). Espiritualidad y sentimientos de soledad sobre la calidad de vida en adultos mayores. Revista Psicología y Ciencia Social, 9, 44-55.

González-Celis, R. A. L., \& Padilla, A. (2006). Calidad de vida y estrategias de afrontamiento ante problemas y enfermedades en ancianos de la ciudad de México. Universitas Psychological, 5, 501509.

González-Celis, R. A. L., \& Sánchez-Sosa, J. J. (2003). Efectos de un programa cognitivo-conductual para mejorar la calidad de vida en adultos mayores. Revista Mexicana de Psicología, 20, 43-58.
INEGI (2009). Instituto Nacional de Estadística, Geografía e Informática. Indicadores Sociodemográficos de México. URL (last checked 23 October 2012).

http://cuentame.inegi.org.mx/impresion/poblacion/esperanza.asp

Jackson, T. (2006). Relationships between perceived close social support and health practices within community samples of American women and men. The Journal of Psychology, 140, 229-246. doi:10.3200/JRLP.140.3.229-246

Johansson, B., Grant, J. D., Plomin, R., Pederson, N. L., Ahem, F., Berg, S. et al. (2001). Health locus of control in late life: A study of genetic and environmental influences in twins aged 80 year and older. Health Psychology, 20, 33-40. doi:10.1037/0278-6133.20.1.33

Lawton, M. P. (1975). The Philadelphia Geriatric Center morale scale: A revision. Journal of Gerontology, 30, 85-89. doi:10.1093/geronj/30.1.85

Litwin, H., \& Shiovitz-Ezra, S. (2006). Network type and mortality risk in later life. The Gerontologist, 46, 735-743. doi:10.1093/geront/46.6.735

Montero, L.-L. M., \& Sierra, C. L. (1996). Escala de bienestar espiritual. Un estudio de validación. La Psicología Social en México, AMEPSO, 6, 28-83.

Nieto, J., Abad, A., \& Torres, A. (1998). Dimensiones psicosociales mediadoras de la conducta de enfermedad y calidad de vida en población geriátrica. Anales de Psicología, 14, 75-81.

Partida, B. V. (2006). Proyecciones de la población de México 20052050. URL (last checked 1 October 2012).

http://www.conapo.gob.mx/es/CONAPO/Proyecciones_de_la_pobla cion_de_Mexico_2005-2050

Pinquart, M., \& Sörensen S. (2001). Gender differences in self-concept and psychological well-being in old age: A meta análisis. The Journals of Gerontology Series B: Pshychological Sciences and Social Sciences, 56, 195-213. doi:10.1093/geronb/56.4.P195

Power, M., Bullinger, M., \& Harper, A. (The World Health Organization Quality of Life Group) (1999). The World Health Organization WHOQoL-100: Tests of the universality of quality of life in 15 different cultural groups worldwide. Health Psychology, 8, 495-505. doi:10.1037/0278-6133.18.5.495

Rivera-Ledesma, A. (2003). Espiritualidad y salud mental en adultos mayores. Sc.Ms. Thesis, México: Facultad de Psicología, UNAM.

Rivera-Ledesma, A., Montero, L.-L. M., González-Celis, R. A. L., \& Sánchez-Sosa, J. J. (2007). Escala de ansiedad ante el envejecimiento de Lasher y Faulkender: Propiedades psicométricas en adultos mayores mexicanos. Revista Salud Mental, 30, 55-61.

Rowe, J., \& Kahn, R. (1997). Successful aging. Gerontologist, 37, 433440. doi:10.1093/geront/37.4.433

Sánchez-Sosa, J. J., \& González-Celis, R. A. L. (2002). La calidad de vida en ancianos. In L. E. Reynoso, \& I. N. Seligson (Eds.), Psicología y salud (pp. 191-218). México: UNAM-Conacyt.

Sánchez-Sosa, J. J., \& González-Celis, R. A. L. (2006). Evaluación de la calidad de vida desde la perspectiva psicológica. In V. Caballo (Ed.), Manual para la evaluación clínica de los trastornos psicológicos. Trastornos de la edad adulta e informes psicológicos (pp. 473-492). Madrid: Pirámide.

United Nations (2007). World economic and social survey 2007. Development in an ageing world. United Nations Publication, 50, 5260.

Viamonte, M. (1993). Al encuentro de la salud y longevidad (pp. 163-179). México: Trillas.

WHOQOL-Group (1996). WHOQOL-BREF. Introduction, administration, scoring and generic version of the assessment. Programme on Mental Health, Geneva: World Health Organization.

WHOQOL-Group (1997). WHOQOL Measuring Quality of Life. Programme on Mental Health. World Health Organization. URL (last checked 1 October 2012).

http://www.who.int/mental_health/PDFdocuments/QOL-WHO-MSA -MNH-PSF-97-4.pdf

WHOQOL-Group (1998a). Development of the World Health Organization WHOQOL-BREF quality of life assessment. Psychological Medicine, 28, 551-558. doi:10.1017/S0033291798006667

WHOQOL-Group (1998b). The World Health Organization quality of 


\section{A. L. GONZÁLEZ-CELIS, J. GÓMEZ-BENITO}

life assessment (WHOQOL): Development and general psychometric properties. Social Science and Medicine, 46, 1569-1585.

doi:10.1016/S0277-9536(98)00009-4

World Bank (2009). Indicadores de desarrollo mundial. URL (last checked 22 October 2012).

http://www.google.com/publicdata?ds=wbdi\&met $\mathrm{y}=\mathrm{sp}$ dyn le00 i

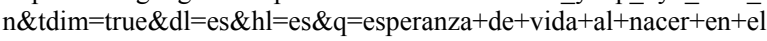

+mundo

Yesavage, J. A., Brink, T. L., Rose, T. L., Lum, O., Huang, V., Adey, M., \& Leiver, V. O. (1983). Development and validation of a geriatric depression screening scale: A preliminary report. Journal of Psychiatric Research, 18, 37-49. doi:10.1016/0022-3956(82)90033-4 